\title{
Naisnäkökulmia sivistystyöhön
}

\author{
Karin Nordberg \& Kers- \\ tin Rydbeck (red. 2001): \\ Folkbildning och genus \\ - det glömda perspek- \\ tivet. MIMER.
}

Vapaa sivistystyö on pohjoismaisessa traditiossa yleensä linkitetty osaksi yhteistä historiaa ja arvomaailmaa, jota on rakennettu viimeisten 150 vuoden aikana täällä Pohjolassa. Esimerkiksi Ruotsissa markkinoidaan folkbildning-käsitettä nimenomaan sen arvotaustaa vasten; folkbildning on vapaan ja demokraattisen yhteiskuntakehityksen edellytys ja väline.

\section{Harvemmin katsotaan} kuitenkin tämän käsitteen lävitse, koska siitä on tullut a priori hyväksyttävä kaikissa poliittisissa leireissä, alltid politiskt korrekt. Mutta entäpäs jos löydämmekin salaisen agendan, kätketyn normiston tämän käsitteen takapihalta?

\section{Linköpingin yliopiston} Mimer-sarjassa on hiljattain julkaistu kriittinen teos, joka valottaa folkbildning-käsitettä naisnäkökulmasta. Toimittajat

Karin Nordberg ja Kerstin Rydbäck ovat Folkbilning och genus-antologiassa pyrkineet kyseenalaistamaan vapaan sivistystyön historiaa; ei nimittäin riitä että yritämme “...täydentää olemassa olevaa historiankirjoitusta naisten osalla."(minun käänn.) Pikemmin on nähtävä myös vapaata sivistystyötä vallankäytön osalta, ja samalla nostaa esille ne sivistystyön alat joissa naisilla on ollut ratkaiseva rooli.

\section{Ruotsissa noin 60} prosenttia virallisen folkbildning-toiminnan osallistujista ovat naisia; kuitenkin heidän osallisuutensa ei näy historian kirjoissa, joissa yleensä mainitaan lähinnä miesten osuudet. Yleensä kirjallinen sivistys on myös arvostettua; tässä yhteydessä kuitenkin kirjastonhoitajien panos unohdetaan tyystin, vaikka tämä ammattikunta on valtaosin korkeasti koulutettujen ja alipalkattujen naisten alaa. Samalla unohdetaan usein myös käytännöllisten ja esteettisten aineiden suuri rooli sivistystössä; esimerkiksi kansanopistoissa nk. kansanopistoäidit (folkhögskolemödrar) ovat Cecilia BååthHolmbergin mukaan kantaneet vastuuta nimenomaan näiden aineiden opetustyöstä.

\section{Voisimme helposti} otaksua että tilanne on Suomessa vastaavanlainen kuin Ruotsissa. Vapaan kansansivistystyön urheat pioneerit ovat kaikki miehiä; nimiä mainitakseni tulevat mieleen ainakin Niilo Liakka, Santeri Alkio, Väinö Voionmaa, Zachris Castrén sekä Urpo Harva. Sivistystyön perinteet ja normit ovat täten muodostuneet vallitsevan patriarkaalisen arvomaailman mukaan. Tämä ei ole estänyt tyttöjen ja naisten osallistumista sivistystoimintaan - useinhan toiminta on avannut väyliä tiedon ja taidon maailmaan monelle suomalaisnaiselle. Mutta asian juoni ei ole siinä, vaan siinä tosiasiassa että naisten arvot, asenteet ja toiminnot ovat jääneet näkymättömiksi.

\section{Kerstin Rydbäck pohtii} kuinka voisimme löytää vaihtoehtoisia kuvia folkbildning- 
toimintaan, jotta naisten panos tulisi selvemmin näkyviin. Rydbäck ehdottaa kolmea eri näkökulmaa:

\section{1) sivistystyö kattaa}

kaiken yhteiskunnallisen toiminnan, jolla on sivistyksellinen tarkoitus; tähän kuuluisi muun muassa naisten äänestysoikeusliike ja radion/television kasvatusohjelmat. (intentionen i stället för institutionen) Tällöin naisten rooli tulee näkyvämmäksi kuin pelkästään sivistysinstituutioiden kautta.

2) sivistystyö on nähtävä osallistujien silmin. Tässä yhteydessä kansakoulujen ja lapsikasvatuksen rooli voimistuu; yleensähän sivistystyötä katsotaan pelkästään aikuisten lukulasien kautta. Suomessakin eräät vapaan sivistystyön toiminta-alueet ovat hyvin naisvaltaisia, esimerkiksi kansalais- ja työväenopistojen kursseilla jopa yli 70 prosent- tia opiskelijoista ovat naisia. Miten tämä näkyy kurssien tuloksissa muulla tavoin kuin sosiaalisen pääoman kasvamisella lienee arvoitus - ainakin asiaa on hyvin vähän tutkittu meillä Suomessa.

\section{3) sivistystä voidaan} tutkia yksityisen ja julkisen rajamailla. Esimerkiksi naisten vapaat ompeluryhmät (syjunta) ovat toimineet naisten strategiana päästä ulos kodin reviiriltä tapaamaan muita naisia - ja keskusteluaiheet eivät takuulla ole vain liittyneet ompeluun! Nämä "juntta-ryhmät" ovat olleet paljon vapaamuotoisempia kuin esim. ohjatut ompelukerhot, mutta niiden emansipatoorinen rooli on varmasti ollut merkittävämpi naisen yhteiskunnallista asemaa ajatellen.

\section{Lisäksi teos sisältää}

lukuisia case-tyyppisiä tapauksia folkbildning-työn arkipäivästä, esim. naiset ja tieto- tekniikka, sukupuoli liikuntakasvatuksessa sekä maahanmuuttajanaisten opintomahdollisuuksista ruotsalaisessa kansanopistossa.

\section{Minuun teos on tehnyt} suuren vaikutuksen ja saanut aikaan ainakin sen, että tulen tulevassa tutkimustyössäni joka käsittelee ruotsinkielistä vapaata sivistystyötä Suomessa - harkitsemaan uudelleen näkökulman valintaa. Opintokeskukseni historiasta voisi nimittäin helposti kertoa enemmän eräiden voimallisten naisten panoksista sivistystyössä, unohtamatta kaikkia niitä lukemattomia naisia jotka ovat osallistuneet ja osallistuvat jatkossakin opintokerho-, kurssi- ja projektitoimintaan. Vapaa sivistystyö on vapaata kansalaistoimintaa vasta sitten, kun tasa-arvo on toteutunut myös toiminnan meta-tasoilla, arvojen maailmassa.

Björn Wallén 